\title{
THE PRODUCTION PROCESS IMPROVEMENT OF UNIT PACKAGE ONE-SIDEDLY LAMINATED
}

\begin{abstract}
In the chapter were put through examination stages of the manufacturing process of the unit package in the enterprise from printing branch. In analysis focused on the identification of disagreements appearing during the production. For determining the structure of the disagreement of unit package a Pareto-Lorenz diagram was used. Classification of causes of the disagreement was carried out with using the FMEA method. In analysis of received results was focused on methods of quality improving of packages in connecting with the Deming cycle, PDCA and the SDCA cycle of the standardization in the purpose of fulfilling requirements of the customer.
\end{abstract}

Keywords: SWOT, the quality, the politics of the quality, the quality management system, the value added, improvement, the Pareto-Lorenz diagram, FMEA, PDCA, SDCA, packages

\section{SWOT analysis of the printing business in Poland in particular the packaging production with printed design}

The printing market in Poland has the very great potential. Thanks to huge investments carried out among others with using union funds it is fortifying its position in Europe. It is one of most quickly involutes sectors of the processing industry. In 2015 value of the sold production of the printing sector amounted to 13.9 milliard zloty - height about 7\% compared with 2014. Poland is a printing broad market in Europe. In Poland an export remains one of the most important factors of the development of the printing sector to outside markets (in 2015 value of 8.3 milliard zloty) (KPMG w POLSCE 2016).

SWOT analysis (Table 1) is presenting a crucial strong point of the Polish printing business such as availability of paper and different materials, an access to the knowhow and modern technologies and qualification of the managing staff. It is recognized as a very positive signal attesting to great development potentialities of this sector. A level of profit margins and different costs of activity are a weak point: from material and of the purchase and the service centre of devices to labor costs.

\footnotetext{
${ }^{1}$ Mgr inż., Czestochowa University of Technology, Faculty of Management, Division of Production Engineering and Safety, e-mail: mielczarek@zim.pcz.pl

${ }^{2}$ Candidate for doctor's degree, Czestochowa University of Technology, Faculty of Management, e-mail: iloonasmo@wp.pl
} 
Table 1. SWOT analysis of the printing sector in Poland

STRONG POINTS
- Availability of paper and different
materials,
- Access to the know-how and the modern
technology,
- Qualification of the managing staff.
CHANCES
- Demand for printing services abroad,
- Demand for printing services in the
country,
- Development of digital source of
communication.

WEAK POINTS
- Level of profit margins,
- Material costs,
- Costs of the purchase and the service
centre of devices.
THREATS
- Requirements and regulations legal -
administrative,
- The economic situation in Poland,
- The economic situation in Europe and in
the world.

Source: own study base on (KPMG W POLSCE 2016)

Amongst the greatest chances of the Polish printing a demand for printing services is placed at home and abroad and development of digital source of communication. The greatest threats are requirements and legal - administrative regulations as well as the economic situation both in Poland and in Europe and in the world.

In the country it is dealing with the press of packages one third of printing enterprises. A food business is the biggest recipient of these products both in Poland and abroad. Although an export is an important factor of the development of the business of packages, a sale of packages is dominating on the domestic market (KPMG IN POLAND 2016). So also on the printing market, particularly the market of packages with the imprint, shaping the quality of the product (packages) requires the wisdom about decision-making processes of the customer and making the ability of the influence on the system (managing by the quality).

\section{Presentation of the enterprise from printing business}

The printing house, in whom a production process was analyzed is a producer of cardboard containers for leading brands in Poland and in Europe. The enterprise specializes in the production of packages in it high processed cardboard improved by hot-stamping, laminate, with UV varnishes whether hybrid - and of blistered cardboard boxes and labels. The company also makes laminated boxes from the corrugated paper, being an object of these examinations. 


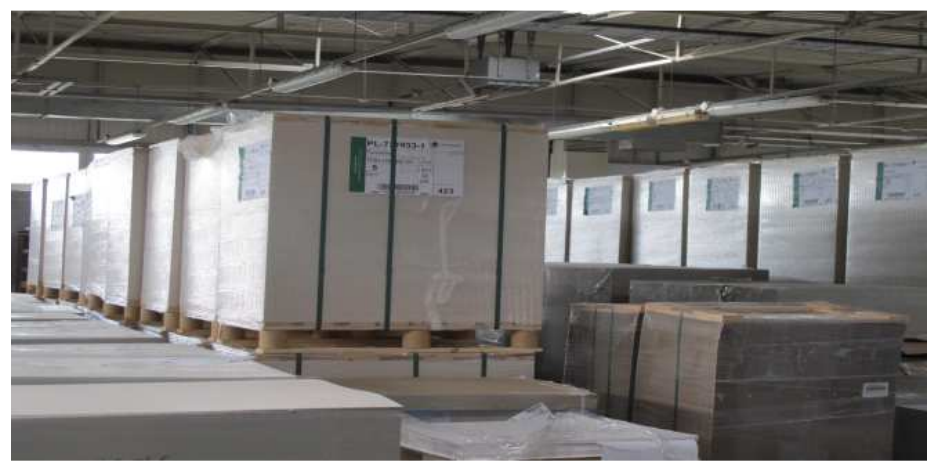

Fig. 1. Magazine of paper in the packages printing house.

Source: own study

It is a family company that for over 30 years is investing in modern technologies as well as it administers the advanced technologically with machines enabling the realization of the most complicated orders. As one of few printing houses in Poland it has multicolored machine Heidelberg with two varnishing towers and UV varnish in the line and machine Heidelberg CD75 - 5 + LX printing in the newest LED UV technology.

A confirmed best quality of a production is characteristic of the printing house with certificate of the conformity to the norm ISO 9001:2008, with Certificate the best Quality of the select sent through European Quality Academy and commitment into the protection of the natural environment confirmed with certificate FSC (PN-EN ISO 9001:2009).

\section{Production process of chosen unit package one-sidedly laminated}

An individual box that is the subject of the research is one-sidedly laminated: from corrugated board 2 - layered with white covered GC1 $250 \mathrm{~g} / \mathrm{m}^{2}$, printed in the colour CMYK+ 0, laminate with foil soft touh, improved with UV varnish (Fig. 2). The box is not being glued together (a finished product is a product in the spread flat form). A manufacturing process of the individual box is the subject of the research is a multistage, complex process, in series parallel, realized at the same time on a few departments. It includes such processes as: the preparation for the press, composition, irradiating CTP plates, giving sheets of paper from the magazine, cutting sheets of paper to the format of the press, printing, laminating with foil software touch, varnishing UV selectively, laminating, stamping, peeling from the openwork pattern, the bulk-breaking, distribution. 
The verified and product conformity to parameters is determined in the Technological Card and with the printing art is a seal of quality controls at every stage of a production process.

The quality of products offered by the company is being identified with created and offered to the customer value. Creating value of the production for the customer according to the M. E. Porter is a chain. It is important, what way the enterprise should shape and measure this value so that it is competitive on the market. Through processes of processing raw materials in the company finished products are coming into existence (ZYMONIK Z., HAMROL A., GRUDOWSKI P. 2013).

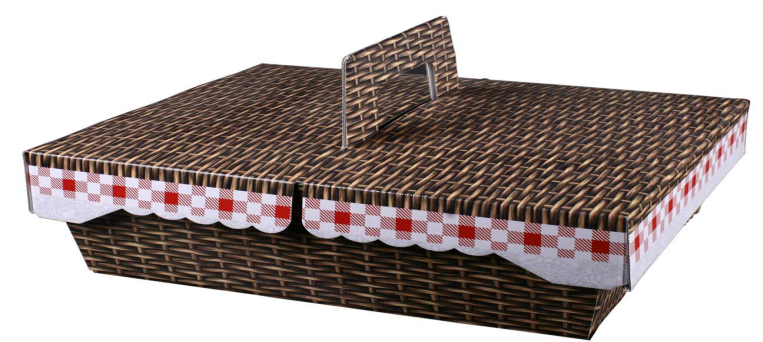

Fig. 2. Finished product - unit package one-sidedly laminated.

Source: own study

Fig. 3 shows a scheme of the manufacturing process of the individual box onesidedly laminated in the technological aspect. Technological process of the individual box one-sidedly laminated consists of the following stages: 1 . Preparing for the print electronic materials sent by the customer, 1a. Storing paper and paints, 1b. Storing the foil soft touch for lamination, 1c. Storing UV varnish, 1d. Storing white microwave, 1e. Preparation of blanking die, 2. Checking the correctness of prepared materials, 2a. Quality control of paper and paints, 2b. Quality control of the foil, 2c. Quality control of UV varnish, 2d. Quality control of white microwave 2W, 2e. Checking making the correctness blanking die, 3. Marking possible amendments in electronic material sent by the customer, 3a. Spending paper and paints from the magazine and the transport to the department of printing machines, $3 \mathrm{~b}$. Edition of the foil to lamination from the magazine and transport to the department of improving, 3c. Spending UV varnish from the magazine and the transport to the department of purification, 3d. Edition of white microwave $2 \mathrm{~W}$ from the magazine and transport to the department of purification, 3e. Transport of blanking die to the department of the bookbinding workshop, 4. Ultimate checking prepared electronic materials of the customer, 5. Carrying assemblies out, 6. Checking assemblies, 7. Handing files over with assemblies to the CTP department, 8. Irradiating and etching offset CTP plates, 9. 
Handing offset plates over to the department of printing machines, 10. Printing sheets, 11. Quality control, 12. Operational transport, 13. Laminating with foil software touch of printed sheets, 14. Quality control, 15. Operational transport 16. Selective varnishing with UV varnish, 17. Quality control, 18. Operational transport, 19. Laminating of microwave $2 \mathrm{~W}$ in with the veneer $\mathrm{GC} 1250 \mathrm{~g} / \mathrm{m}^{2}, 20$. Quality control, 21. Operational transport, 22. Stamping sheets, 23. Quality control, 24. Operational transport, 25. Picking use of the openwork pattern, 26. Quality control, 27. Transport of ready boxes for the magazine of products, 28. Storing final goods.

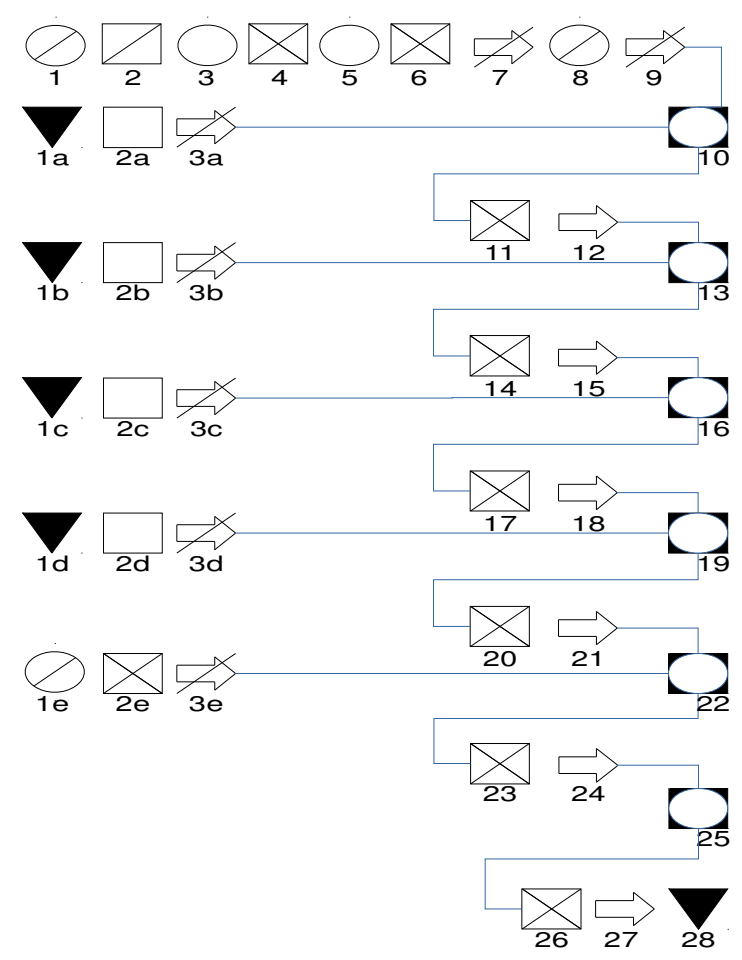

Fig. 3. Manufacturing process of the unit box one-sidedly laminated in the technological aspect.

Source: own study

\section{Quantitative presenting to the disagreement of chosen unit package one-sidedly laminated}

In the purpose of the identification of factors influencing the quality of produced individual packages one-sidedly laminated in the examined enterprise a diagram Pareto-Lorenz was applied (Table 2). 
Table 2. Disagreements appearing during the unit individual packages one-sidedly laminated

\begin{tabular}{|c|c|c|c|}
\hline $\begin{array}{l}\text { Symbol of the } \\
\text { disagreement }\end{array}$ & $\begin{array}{c}\text { Frequency of the } \\
\text { appearance }\end{array}$ & $\begin{array}{c}\text { Percentage share } \\
(\%)\end{array}$ & $\begin{array}{l}\text { Accumulated } \\
\text { value }(\%)\end{array}$ \\
\hline $\mathbf{N}_{2}$ & 42 & 27,63 & 27,63 \\
\hline $\mathbf{N}_{6}$ & 39 & 25,66 & 53,29 \\
\hline $\mathbf{N}_{10}$ & 35 & 23,03 & 76,32 \\
\hline $\mathbf{N}_{9}$ & 11 & 7,24 & 83,56 \\
\hline $\mathbf{N}_{8}$ & 9 & 5,92 & 89,48 \\
\hline $\mathbf{N}_{4}$ & 5 & 3,29 & 92,77 \\
\hline $\mathbf{N}_{7}$ & 5 & 3,29 & 96,06 \\
\hline $\mathbf{N}_{3}$ & 3 & 1,98 & 98,04 \\
\hline $\mathbf{N}_{5}$ & 2 & 1,31 & 99,35 \\
\hline $\mathbf{N}_{1}$ & 1 & 0,65 & 100 \\
\hline
\end{tabular}

Source: own study

This method allows organizing data in terms of their importance, so to deal with these problems that solving will bring in the greatest benefits. Moreover it enables to show sources of coming into existence of unnecessary costs, letting in consequence lead for limiting them (BRAJER-MARCZAK R. 2015). The diagram (Fig. 4) was made out for the disagreement appearing in period 12 months.

How results from the diagram, $76.32 \%$ disagreements during production of the individual packages are responsible three causes:

- $\mathbf{N}_{2}$ - flowing glue from the veneer and the white microwave $2 \mathrm{~W}$,

- $\mathbf{N}_{6}$ - lack of fitting the veneer and the white microwave $2 \mathrm{~W}$,

- $\mathbf{N}_{\mathbf{1 0}}$ - stresses causing rounding of the package. 


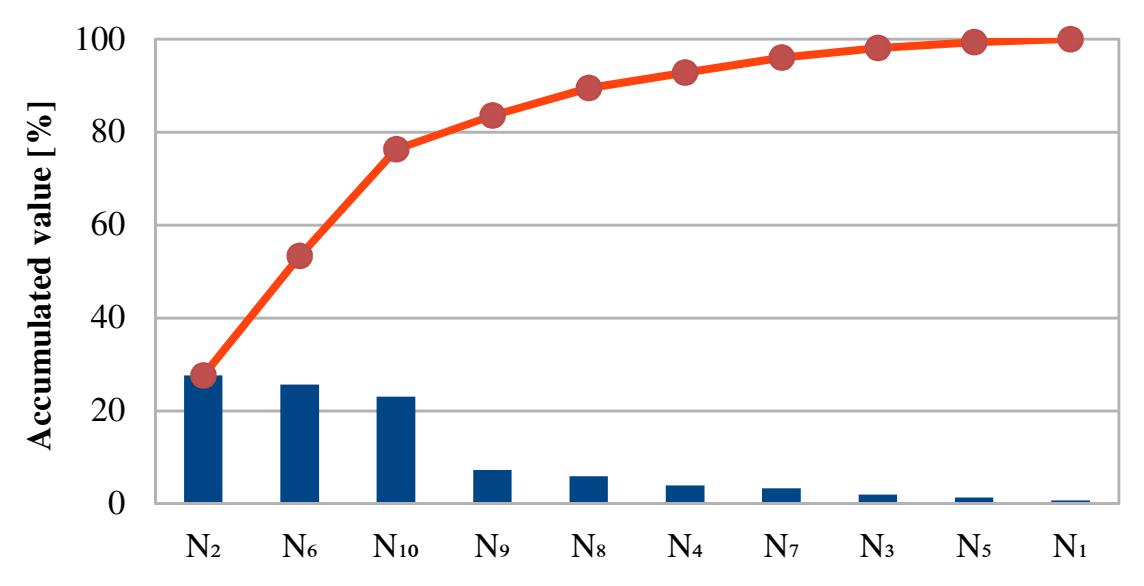

Symbol of discrepancy

Fig. 4. Pareto-Lorenz diagram during the production individual packages one-sidedly laminated.

Source: own study

Remaining $23.68 \%$ disagreements are caused by:

- $\mathbf{N}_{\mathbf{9}}$ - lack of fitting UV varnish to the print,

- $\mathbf{N}_{\mathbf{8}}$ - pulling away press in the stack,

- $\mathbf{N}_{4}$ - cracking laminated sheets in the process of stamping,

- $\mathrm{N}_{7}$ - stratifying veneers from the white microwave $2 \mathrm{~W}$,

- $\mathbf{N}_{3}$ - air bubbles under the foil soft touch,

- $\mathbf{N}_{5}$ - lack of fitting the line of cutting with respect to the press

- $\quad \mathbf{N}_{\mathbf{1}}$ - stratifying of foil soft touch from the veneer.

The enterprise should pay attention to the course of laminating process on the department of purification. Eliminating these causes will let lowering the indicator $76.32 \%$ of discrepancies during the production of individual packages one-sidedly laminated.

\section{Classification of disagreement causes for chosen individual packages one-sidedly laminated with using the FMEA method}

In the purpose of elaborating analysis of the quality level during production of individual packages one-sidedly laminated was applied FMEA method. This method enables to detect causes of the problem as well as is identifying possible problems to become known in the future and effects who influence the quality of processes. An FMEA is often the first step of a system reliability study. It involves reviewing as 
many components, assemblies, and subsystems as possible to identify failure modes, and their causes and effects. For each component, the failure modes and their resulting effects on the rest of the system are recorded in a specific FMEA worksheet. Successful FMEA activity helps identify potential failure modes based on experience with similar products and processes or based on common physics of failure logic. It is widely used in development and manufacturing industries in various phases of the product life cycle. Effects analysis refers to studying consequences of those failures on different system levels (BORKOWSKI S. 2012).

For every disagreement, it cause and the effect a probability of the appearance was definite (LPW), meanings (LPZ) and detecting (LPO). Table 3 is shoving the risks level of disagreement appearance during the production of individual packages onesidedly laminated.

Table 3. Failure mode and effects analysis of disagreement during the production process of individual packages one-sidedly laminated

\begin{tabular}{|c|l|l|c|c|c|c|}
\hline Symbol & Potential failure mode & Potential causes of failure & LPZ & LPW & LPO & LPR \\
\hline $\mathbf{N}_{\mathbf{1}}$ & Recycling & Thin glue & 9 & 5 & 1 & 45 \\
\hline $\mathbf{N}_{\mathbf{2}}$ & Reduced quality & Thin glue & 4 & 6 & 10 & 240 \\
\hline $\mathbf{N}_{\mathbf{3}}$ & Recycling & $\begin{array}{l}\text { Too small pressure of rollers, } \\
\text { the low temperature }\end{array}$ & 8 & 4 & 3 & 96 \\
\hline $\mathbf{N}_{\mathbf{4}}$ & Recycling & $\begin{array}{l}\text { Applying too small size of } \\
\text { creasing matrix }\end{array}$ & 7 & 4 & 5 & 140 \\
\hline $\mathbf{N}_{\mathbf{5}}$ & Recycling & Incorrect the machine setting & 8 & 5 & 2 & 80 \\
\hline $\mathbf{N}_{\mathbf{6}}$ & Reduced quality & Thin glue & 4 & 6 & 9 & 216 \\
\hline $\mathbf{N}_{\mathbf{7}}$ & Recycling & $\begin{array}{l}\text { Thin glue, the too small } \\
\text { pressure of rollers }\end{array}$ & 7 & 3 & 4 & 84 \\
\hline $\mathbf{N}_{\mathbf{8}}$ & Recycling & $\begin{array}{l}\text { Too big giving water on } \\
\text { printing machine }\end{array}$ & 8 & 1 & 6 & 48 \\
\hline $\mathbf{N}_{\mathbf{9}}$ & Reduced quality & Human errors & 5 & 2 & 7 & 70 \\
\hline $\mathbf{N}_{\mathbf{1 0}}$ & Reduced quality & $\begin{array}{l}\text { Applying the microwave } \\
\text { about wrong direction }\end{array}$ & 4 & 6 & 8 & 192 \\
\hline
\end{tabular}

Source: own study 
With the help of the FMEA method were shown breaking points appearing in the production cycle of individual packages one-sidedly laminated. From analysis results that the most important discrepancies from immediately decisions point of view are: flowing glue from the veneer and the white microwave $2 \mathrm{~W}$, lack of fitting the veneer and the white microwave $2 \mathrm{~W}$, stresses causing rounding of the package. It causes lover quality of final product ant it is a result of the inappropriate glue density and of applying the microwave with wrong direction.

Correcting action should concentrate on:

- improvement the production and managing staff,

- changing of the raw material (glue to laminating),

- increased control of the raw material absorbed to the magazine,

- paying attention to the conformity of the worker activity with the instruction of acting on a given workstation,

- correcting the schedule of the machines inspection.

\section{Proposals of process improvement}

Providing the appropriate and stable quality of products is a kindness of having the effective system of quality management. It allows achieving the loyalty (attachments of customers). Politician of constant improvement and moving the main focus in direction of preventing is a potential source of quality cost reduction at the same time the all costs (STADNICKA D., PACANA A. 2016).

Pareto-Lorenz method is a technique that make possible to identify the most important reasons which has essential influence on the quality of goods. It was shown that process of laminating on the department of purification causes eliminating of the incompatibility there ensuing will let lowering the indicator $76.32 \%$ of discrepancies during the production of individual packages one-sidedly laminated.

Thanks to the quality management method such as FMEA it was possible to fix potential faults and their importance what has an influence on the quality and future functioning of the product. The FMEA method showed that the greatest fatal error was flowing glue from the veneer and the white microwave $2 \mathrm{~W}$, lack of fitting the veneer and the white microwave $2 \mathrm{~W}$. It is providing that the severe error is appearing during the process of laminating on the department of purification.

On the basis of received results it should be introduce the appropriate system of the quality improvement. It can determine the source of the problem, taking correcting and preventive action. Very important is also connection the manufacturing process with the Deming cycle, with PDCA and the standardization cycle SDCA: 
improvement with small steps, the standardization of processes, using ideas, information, the knowledge and experiencing of workers.

\section{Bibliography}

1. BoRKOWsKI S. 2012. Tradycyjne narzędzia zarządzania jakością. Teoria i praktyka. Oficyna Wydawnicza Stowarzyszenie menadżerów Jakości i Produkcji. Częstochowa.

2. BRAJER-MARCZAK R. 2015. Doskonalenie zarządzania jakościq procesów i produktów w organizacjach. Wydawnictwo Uniwersytetu Ekonomicznego we Wrocławiu. Wrocław.

3. Dziuba S., SzOŁTYSeK K., KozYra C. 2011. Application of FAM-Fail Assessment Method to optimization of unit costs of producing flours for special purposes. In: Borkowski S., Krynke M. (Eds.). Improvement of Production Processes. TRIPSOFT.

4. KPMG w POLSCE 2016. Rynek poligraficzny i opakowań z nadrukiem w Polsce. Raport KPMG w Polsce opracowany we współpracy z Polskim Bractwem Kawalerów Gutenberga. Polskie Bractwo kawalerów Gutenberga. Warszawa.

5. Stadnicka D., PaCANa A. 2016. Budowa i rozwój systemów zarzadzania jakościa. Oficyna Wydawnicza Politechniki Rzeszowskiej. Rzeszów.

6. ZyMONIK Z., HAMrOL A., GRUDOWSKI P. 2013. Zarzadzanie jakościa i bezpieczeństwem. Polskie Wydawnictwo Ekonomiczne. Warszawa. 